\title{
THE PARADOXES OF NECESSITATION AND IONIC-ENTAILMENT
}

JOHN wOODS

University of Toronto

1. Any system of implication attempting the reconstruction of an intuitive notion of logical entailment for which analogues of the classical S2-paradoxes are underivable is interesting in its own right. Of at least equal interest are results of such systems by which one must distinguish two non-S2 relations of entailment only one of which is transitive. Just these consequences form the foundation of Casimir Lewy's disposal $^{2}$ of an enchanting bit of modal mischief which, after its founder, I shall call Casimir Lewy's Paradox, more briefly, CLP. I wish to enquire whether such modal proliferation is necessary or supportable.

2. CLP. Consider the three true sentences

(D) Caesar is dead $\equiv$ Russell is a brother. ${ }^{2}$

(E) Russell is a brother $=$ Russell is a male sibling.

(F) Caesar is dead $\equiv$ Russell is a male sibling.

Now, it would appear that

(7) ${ }^{r} D \& E$ ? entails $F$.

(8) $E$ is necessary.

(9) $D$ is contingent.

(10) $F$ is contingent.

1 In Casmir Lewy, John Watling and P. T. Geach, "Entailment", Proceedings of the Aristotelian Society, Supplementary Volume LVIII, 1958.

2 ' and (implied) numbering. 
Hence that

(11) $D$ entails $F$.

(12) $\left.{ }^{\ulcorner} D \& F\right\urcorner$ entails $E$.

(13) $D$ entails $E$.

But surely, says Lewy, $D$ does not entail $E$. So saying, Lewy departs S2 wherein, of course, $D$ does entail $E$. We remark that if $E$ entails that $E$ is necessary, then by the necessity of ${ }^{r} E$ entails $E$ ? , these two propositions would be logically equivalent. But if they are logically equivalent Lewy thinks his dilemma is solved, for he denies that the conjunction of $D$ and $F$ entails the necessity of $E$ even though it entails the truth of $E$. But if the truth of $E$ is logically equivalent to the necessity of $E$, then ${ }^{\mathrm{r}} D \& F^{\mathrm{T}}$ must entail the necessity of $E$. But Lewy thinks that the truth of $E$ is not equivalent to its necessity. If Lewy's worry is a legitimate one, then his dilemma is solved: for it seems perfectly clear that any necessary proposition entails its own necessity. To show this, we need only assume:

( $\alpha$ ) if $p$ does no entail $q$ then $p$ o $\sim q$, reading ' $o$ ' as ' $i s$ consistent with'; and either

( $\beta)$ if $p$ is consistent with $q$, then if $\mathrm{M}(p \vee q)$ then $\mathrm{M}(p \& q)$, reading ' $\mathrm{M}$ ' as ' $i t$ is possible that'; or

$(\gamma)$ if $p$ is consistent with $q$, then $\mathrm{M}(p \equiv q)$, reading ' as 'is materially equivalent to'.

Consider any necessary proposition, ${ }^{r} \mathrm{p} v \sim p^{7}$; if ${ }^{r} p \mathrm{v} \sim p$ ? does not entail ${ }^{\Gamma} \mathrm{L}\left(p \vee \sim p^{\top}\right.$ (i.e. its own necessity) then we have it, by $(\alpha)$, that $\Gamma_{p} \mathrm{v} \sim p^{7} \circ \Gamma_{M}(p \& \sim p$, which is surely false. If ${ }^{r} p \mathrm{v} \sim p^{\urcorner},{ }^{r} \mathrm{M}(p \& \sim p\urcorner$, then if $\mathrm{M}((p \mathrm{v} \sim p)$ v $\mathrm{M}(p \& \sim p))$ then $\mathrm{M}((p \mathrm{v} \sim p) \& \mathrm{M}(p \& \sim p))$. But since ${ }^{\top} \mathrm{M}\left(p \& \sim p \sim^{\top}\right.$ is necessarily false so too is ${ }^{\top} \mathrm{M}((p \mathrm{v} \sim p)$ \& $\mathrm{M}(p \& \sim p))$, and by modus tollens so is ${ }^{\mathrm{M}} \mathrm{M}((p \mathrm{v} \sim p) \mathrm{v}$ $\mathrm{M}(p \& \sim p))^{7}$, which, of course, is absurd. Similarly, by condition $(\gamma)$ on consistency, it is nonsense to deny that 
${ }^{\ulcorner}(p \vee \sim p)^{\urcorner}$entails ${ }^{\ulcorner} \mathrm{L}(p \vee \sim p)^{\urcorner}$, for it is plainly not pos. sible for ${ }^{\Gamma}(p \vee \sim p)^{7}$ to be the material equivalent of ${ }^{r} \mathrm{M}(p \& \sim p)^{\urcorner}$. Yet it is doubtful whether these devices $\alpha$, $\beta, \gamma$ are open to me. As I have elsewhere ${ }^{3}$ attempted to show, they are strong enough to give not only S2-paradoxes but actually to establish the logical equivalence of S2-implication (strict implication) and entailment. ${ }^{*}$ On the methodological principle that questions in dispute ought not balatantly to be begged, the discussion might better be moved to Lewy's home field.

How then does one meet Lewy's Problem? Lewy's answer is that, "We must suppose that there are two uses of 'entails", each distinct from 'strictly implies', "in one of which $D$ does entail $F$, but in the other of which it does not; and that whilst entailment, in its second use, is transitive, it is not transitive in the first use." The sense of entailment in which $D$ does entail $F$, and which is not transitive, Lewy calls necessitation, and he thinks that his puzzle is solved by reading step (11) as " $D$ necessitates $F$ ". Now, given that $D$ entails $D$ (hence that $D$ necessitates $D)$, we say that $D$ necessitates ${ }^{\ulcorner}(D \& F)^{\urcorner}$. And because ${ }^{\ulcorner}(D \& F)^{7}$ necessitates $E$, we apply the rule of hypothetical syllogism and assert that $D$ entails $E$. But be. cause necessitation is not transitive, hypothetical syllogism may not be invoked. And so it would appear that CLP is resolved.

3. Necessitation, But what is this use of "entails', which is non-transitive, and which Lewy calls "necessitation"?

Definition:

$p$ necessitates $q$ iff $(r) \quad(\sim \mathrm{M}(r$ is a reason for $p$ and $r$ is not reason for $q$ )).

3 John Woods, "On How not to Invalidate Disjunctive Syllogism," Logique et Analyse, 32, December 1965.

4 See John Woods, "Logical Consistency and the Equivalence of Strict Implication and Entailment", Mimeographed, Department of Philosophy, University of Toronto, 1969.

s Casmir Lewy, John Watling and P. T. Geach, Op. cit. p. 132. 
(In what follows I shall sometimes speak of the set of true necessitation-statements as the necessitation-set.)

The definition is equivalent to,

$p$ necessitates $q$ iff $(r)^{\Gamma}(r \text { is a reason for } p)^{7} \rightarrow^{\mathrm{r}}(r$ is reason for $q)^{7}$ )*

An immediately troublesome feature of necessitation is that its definition simply will not support the claims for its nontransitivity. On the contrary. Necessitation turns out to be unrestrictedly transitive. Consider the two necessitation statements, ${ }^{\ulcorner}(p \text { Nec } q)^{\urcorner}$and ${ }^{\ulcorner}(q \text { Nec } s)^{\urcorner}$. Now if $p$ Nec $q$, then $\Gamma(r \text { is a reason for } p)^{\urcorner} \rightarrow \Gamma(r \text { is a reason for } q)^{\urcorner}$. And if ( $q$ Nec s), then ${ }^{\Gamma} r$ is a reason for $q^{\top} \rightarrow{ }^{\Gamma} r$ is a reason for $\mathrm{s}^{\urcorner}$. So, from ${ }^{\mathrm{r}} p$ Nec $q^{7}$ and ${ }^{\mathrm{r}} q$ Nec $s^{7}$ we have:

(i) $r_{r}$ is a reason for $p^{\urcorner} \rightarrow{ }^{r} r$ is a reason for $q^{\urcorner}$; and

(ii) $r_{r}$ is a reason for $q^{\urcorner} \rightarrow \Gamma_{r}$ is a reason for $s^{\urcorner}$; and so, by the transitivity of strict implication, that ${ }^{r_{r}}$ is a reason for $p^{7} \rightarrow r_{r}$ is a reason for $s^{7}$. Yet by the the definition of necessitation, we have it that $p$ Nec $s$ and that necessitation after all is unrestrictedly transitive. ${ }^{5}$ Thus Lewy has not, by these manoeuvres, managed to solve his puzzle; for even if we agree that (11) should read " $D \operatorname{Nec} F$ ", in the end there is no way of avoiding the truth of $D$ entails $E$. If anything, CLP provides additional grounds for accepting the paradox that any proposition entails any necessary proposition.

Nor can Lewy consistently maintain the distinctness of necessitation and strict implication. In the system of necessitation, Lewy does not want it to be true that the conjunction of $p$ and $\sim p$ necessitates $p$. Lewy concedes that the truth of the proposition that John is a brother and yet not male is a reason, "in fact a conclusive reason", for ${ }^{\Gamma}$ (John is male and yet is not male) ${ }^{7}$; but it is not a reason for ${ }^{5} \mathrm{John}$ is male ${ }^{7}$ nor for ${ }^{\ulcorner} \mathrm{John}$ is not a male ${ }^{\urcorner}$. Since if is agreed that ${ }^{\mathrm{r}} p \& \sim p^{\urcorner}$ $\rightarrow p$, Lewy thinks it follows that necessitation is not the

- Editor's Note. The symbol ' $\rightarrow$ ' is here used with the meaning 'strictly implies'. Given certain printing problems, the author gave us his kind authorization to do so.

6 This is essentially Watling's point in $O p$. cit, p. 145. 
same as strict implication. If we are to see why this is so, we need to know how Lewy intends us to understand the phrase "... is a reason for". On this crucial point, we learn scarcely more than that $r$ is a reason for $p$ if any of the following is true:

(1) since $r$ is true, $p$ must be true.

(2) since $r$ is true, $p$ is true.

(3) if $r$ is true, $p$ must be true.

(4) if $r$ is true, $p$ is true.

(5) if $r$ were true, $p$ would necessarily be true.

(6) if $r$ were true, $p$ would be true.

It is important that, for $r$ to be a reason for $p$, it is not necessary that $r$ entail $p$, nor that $r$ be a conclusive reason for $p$, nor that $r$ be true.

How can it be believed that ${ }^{r} p \& \sim p$ does not necessitate $p$ ? Surely if ${ }^{r} p \& \sim p^{\top}$ were true $p$ woud also be true. What reason is there for the antecedent which is not a reason for the consequent? Clearly the coherence of Lewy's conception of necessitation hangs upon the intelligibility of his conception of 'being a reason for'. Since Lewy has not given us necessary conditions for being a reason for it just might be arguable that although there are some reason for ${ }^{{ }} p \& \sim p$ which must strictly be reason for $p$ as well, it is nontheless possible that there is at least one reason for the former which is not a reason for the latter. But how are we to tell? More generally, we cannot ascertain whether ${ }^{r_{p}}$ Nec $\left.q\right\urcorner$ until we are satisfied that there is no possibility that something is a reason for $p$ which is not a reason for $q$. Just how are we to satisfy ourselves of this? Not I trust, by the systematic scrutiny of reasons for $p$ and reasons for $q-$ a procedure which terminates only by exhausting all reason for $p$. Waiving cardinality difficulties, no one will doubt the practical disadvantages of such procedures, but this is of no importance. What really counts here is not the difficulty of this method of necessitation-discovery, but rather its impossibility. It is not that these are discoveries which are hard to make, but 
rather that they are impossible to make. There are two reasons for this: the vagueness of 'being a reason for', and the related possibility that for any putative necessitation statement there exists some reason or other which is a reason for the antecedent but not necessarily for the consequent - which just is the possibility that all necessitation-statements are false.

4. The vagueness of being a reason for. That 'being a reason for' is vague requires no argument. But not so the claim that it is so vague as to resist meaningful application. Intuitively, one might think that ${ }^{\top} p \& \sim p^{\top}$ does not necessitate $q$. We put 'Tommy Tweed is married and Tommy Tweed is not married ${ }^{\top}$ for ${ }^{\top} p \& \sim p^{\top}$ and ${ }^{\top}$ There's a witch at Fort Chimo ${ }^{7}$ for $q$. Could it be that the proposition that everyone named Tommy is married and not married provides a reason for the antecedent which is not necessarily a reason for the consequent? If this were so we should have some rough idea of what Lewy is driving at. Surprisingly, this seems not to be so, in the light of Lewy's explicit denial that ${ }^{\top} p \& \sim p{ }^{\top}$ necessitates $p$. But in whatever sense the proposition that everyone named Tommy is married and not married is a reason for Tommy Tweed being both married and not married which is not necessarily a reason for there being a witch at Fort Chimo, if it is not a reason for the proposition that Tommy Tweed is married it is not for a sense of 'reason' that I can understand. Until the concept of 'being a reason for' is given some determinate contours it simply will not serve to explain necessitation. I can think of just two plausible reasons for thinking that there is no reason which is a reason both for ${ }^{\top} p \& \sim p^{\urcorner}$and also for any $q$ (including the cases, $q=p$, and $q=\sim p$ ). Consider a con. ception of 'being a reason for' by which false propositions can be reasons but logically false propositions cannot be. But if a self-contradiction cannot be a reason for any pro. position -if it is logically impossible for a self-contradic. 
tion to be a reason for anything - it is logically impossible for any self-contradiction to be both a reason for a self. contradiction and for some other proposition as well. Then, unless non-self-contradictory proposititons could be reasons for self-contradictions, all necessitation-statements whose antecedents are self-contradictory come out true. On the other hand, a conception of 'being a reason for' which would allow us to speak of a non-self-contradictory proposition being a reason for a self-contradiction is all too easily manoeuvred into a defense of the thesis that $\left.{ }^{{ }^{r}} p \& \sim p\right\urcorner$ Nec $p$.

Similarly, if one were to argue that nothing wahtever could be a reason for a self-contradiction and hence that $\left.{ }^{\Gamma} p \& \sim p\right\urcorner$ cannot necessitate $p$, one would simply have contradicted oneself. If it is impossible for any $r$ to be a reason for ${ }^{\prime} p \& \sim p$, then it is impossible for any $r$ to be a reason for $\left.{ }^{r} p \& \sim p\right\urcorner$ and not a reason for any $q$; which, again, is just to say that all necessitation-statements with impossible antecedents are true.

The fuzziness of 'being a reason for' creates mischief, of another sort, which threatens to void the necessitation-set, to make the very concept of necessitation empty. For it could be that Lewy has in mind an epistemic or psychological conception of 'being a reason for' such that $r$ is a reason for $p$ only if not only does the truth of $r$ provide some sort of grounds for the truth of $p$, but also that when someone is confronted with $r$ he will believe or tend to accept $p$, on the grounds that $r$. But this way of construing 'being a reason for' is ruinous for Lewy's programme. Given any two state. ments, $p$ and $q$, it is always possible for $r$ to be a reason, in this sense, for the one without it being a reason, in the same sense, for the other simply because it is always logically possible to believe one thing without thereby believing or tending to accept something entailed or otherwise implied by it. Thus, on this view of 'being a reason for', all necessitation-statements are false. It might be possible to meet the objection by imposing a suitably strong rationality assump- 
tion by which anything which to an ideally rational agent is a reason for $p$ is a reason for $q$. But then the notion of necessitation dos not even purpor be an alethic modality, and in its stead we have something like rational necessitation, an epistemic or doxastic modality. While this may well be a proposal worth following up, it can be seen at once that $r_{p} \& \sim p^{\urcorner}$will necessitate $p$, since it is not rational to accept $r$ as a reason of degree $n$ ( $n$ very small) for ${ }^{r} p \& \sim p^{7}$ but not accept it as a reason of at least degree $n$ for $p$.

What is more, thanks to the strange properties of 'being a reason for', Lewy cannot be right in asserting that $D$ Nec $F$. For here there is a reason for the antecedent being true which is not a reason for the consequent being true. "Were $\sim F$ and $(\sim F$ entails $D)$ true then $D$ would be true" expresses a reason for $D$ which is not a reason for $F$; whence (if we are to believe Lewy's six exemplifying glosses on 'being a reason for'), contrary to Lewy, $D$ does not necessitate $F$. For that matter, all necessitation-statements must fail since, for any statement ${ }^{r} p$ Nec $q^{7}$ there is always the statement ${ }^{\top}$ Were it true that $\sim q$ and that $(\sim q$ implies $p)$ then $p$ would be true ${ }^{7}$ which expresses a reason for $p$ and not for $q$.

5. Ionic-entailment. Lewy's second use of 'entails', in which $D$ does not entail $F$, and which is transitive, is explained to be that relation which obtains between $p$ and $q$ when it is true to say that $p$ alone, or $p$ by itself, entails $q$. I will call this 'ionic-entailment' and yield to the temptation to abbreviate it as 't.E.'

\section{Definition:}

\section{$p$ I.E. $q$ iff (a) $p$ Nec $q$.}

(b) It is possible to show that $p \rightarrow q$ without having previously shown or assumed the truth of some proposition $r$, such that $r$ is different from any Russellian formal implication, $s$, where $p$ or a conjunct of $p$ is 
in the range of the antecedent of $s$, and $q$ or a conjunct or disjunct of $q$ is in the range of the consequent of $s$.

The formidable mysteriousness of condition (b) is partly cleared away by Lewy's proposal to distinguish

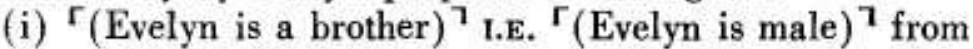
(ii) $D$ i.E. $F$.

Lewy thinks that the truth of (i) is secured by the fact that its antecedent necessitates its consequent, together with the fact that there is a formal logically necessary implication, $P$, viz. "There is nobody who is a brother and is not male ${ }^{\top}$, such that the antecedent of (i) is in the range of the antecedent of $P$, and the consequent of (i) is in the range of $P$ 's consequent. By Lewy's lights $P$ then licenses the inference from the antecedent of (i) to its consequent.

Yet, when we come to (ii), Lewy believes it impossible to show that $D \rightarrow F$ without violating the second condition of ionic-entailment, without that is, invoking a principle which is not a formal implication of the kind required. In particular Lewy believes that one must show that $E$ in order to show that $D \rightarrow F$, where $E$ is not a formal implication in the required sense.

However, even if we grant that $E$ does not give the right kind of inference rule, it doesn't seem to be the case that there is no other principle which fits Lewy's specifications. ${ }^{\ulcorner} D \rightarrow F^{\urcorner}$can be shown by appeal to the principle which asserts that there are no material equivalences with identical antecedents and with consequents which mutually entail one another, which are material equivalences which cannot be inferred from one another. Or better: "There is nothing which is materially equivalent to the statement that $x$ is a brother which is not materially equivalent to the statement that $x$ is a male sibling??

7 And what of the principles of inference invoked by S2's proofs? (C.I. Lewis and C.H. Langford, Symbolic Logic, New York, 1932, p. 250ff.) Surely these are formal implications in the appropriate sense; in which case each step 
In sum, on Lewy's own analysis of ionic-entailment it cannot be denied that $D$ ionically-entails $F$. Not only does $D$ Nec $F$, but it is possible to prove that $D \rightarrow F$ without the use of a non-formal Russellian implication. This is disastrous for Lewy's solution of the puzzle, for it seems to mean that in neither sense of 'entails' is the paradox removed. If we read 'Nec' for 'entails' in step (11), the conclusion follows from the transitivity of necessitation. If we read it as 'ionically-entails', (11) can be shown to be true, and the paradoxical conclusion follows, thanks to its transitivity.

We have the further consequence of Lewy's explications of entailment that in neither sense of 'entails' are Lewy's proofs of the paradoxes discredited - a consequence of no little irony in view of Lewy's claim that what constitutes his own puzzle is the derivation of a proposition which instantiates one of the S2-paradoxes. Consider, for example, the S2-proof of the second paradox. ${ }^{8}$ It is easily verified that each step in the argument is linked by Lewy's ionic-entailment, which is transitive. Thus $p$ ionically-entails $(\sim q \vee q)$, and CLP being a case of this, is no paradox at all. And even if we say instead that, at best, the steps in the proof are connected by necessitation, since that relation has been shown to be transitive, the proof gives the same, paradox-removing, result.

Thus, on either application of Lewy's concepts of entailment, his own puzzle not only is not given the desired solution, but is actually provided with additional support as indeed are the S2-paradoxes.

of the proofs ionically-entails its suecessor. And given the acknowledged transitivity of ionic-entailment, Lewis' paradoxes hold. But if Lewis' Paradoxes hold, CLP is solved, for now it will be clear that $D$ does entail $E$.
(1) implies $\mathrm{r}_{(\mathrm{p} \& \sim q)}^{\mathrm{p}} \sim \mathrm{q}(\mathrm{p} \& q)$ ᄀ
(1)
(2) implies $\Gamma_{p} \&(\sim q \& q)^{7}$
(3) implies $r_{\sim q v}^{\sim} q^{7}$
Q.E.D. 
RESUMEN

El autor examina la siguiente paradoja (CLP) planteada por Casmir Lewy $:^{1}$

Considérense las tres oraciones verdaderas

(D) César ha muerto $\equiv$ Russell es hermano. ${ }^{1}$

(E) Russell es hermano $\equiv$ Russell es hermano varón.

(F) César ha muerto $\equiv$ Russell es hermano varón.

parecería que

(7) $\ulcorner D \& E 7$ implica $F$.

(8) $E$ es necesaria.

(9) $D$ es contingente.

(10) $F$ es contingente

Por lo tanto

(11) $D$ implica $F$.

(12) $\Gamma D \& F\urcorner$ implica $E$.

(13) $D$ implica $E$.

Lewy es de la opinión de que $D$ no implica a $E$. Con esto Lewy se aleja de la paradoja $\mathbf{S} 2$ donde $D$ implica a $E$. Ahora, si $E$ implica que $E$ es necesaria, entonces, por la necesidad de $\Gamma E$ implica a $E\urcorner$, estas dos proposiciones serian equivalentes. Pero Lewy piensa que si son lógicamente equivalentes su dilema está resuelto, puesto que él niega que la conjunción de $D$ y $F$ implique la necesidad de $E$ aunque implique la verdad de $E$. Pero, si la verdad de $E$ es lógicamente equivalente a la necesidad de $E$, entonces $\Gamma D \& F\urcorner$ debe implicar la necesidad de $E$. Pero Lewy piensa que la verdad de $E$ no es equivalente a su necesidad. Si la preocupación de Lewy es legítima su dilema está resuelto porque parece claro que cualquier proposición necesaria implica su propia necesidad. Según Lewy "debemos suponer que hay dos usos de "implica", cada uno distinto de "im. plica estrictamente', "en uno de los cuales $D$ implica a $F$, mientras que en el otro no, y que mientras la implicación, en su segundo uso es transitiva, en el primero no lo es". El sentido de implicación en

1 '”' se leerá como 'es equivalente materialmente a'. 
el que $D$ implica a $F$ y que no es transitivo, lo llama Lewy necesitación y piensa que sus problemas se resuelven leyendo (11) como " $D$ necesita $F "(D$ Nec. $F$ ). Dado que $D$ implica a $D$ (y por lo tanto $D$ necesita $D)$ podemos decir que $D$ necesita $\ulcorner(D \& F)\urcorner$, y puesto que $\left.{ }^{\Gamma} D \& F\right]$ necesita $E$ aplicamos un silogismo hipotético y afirmamos que $D$ implica a $E$. Pero puesto que la necesitación no es transitiva, no se puede acudir al silogismo hipotético. Parecería así que la CLP se resuelve.

Necesitación. ¿Cuál es este uso de 'implica' que no es transitivo $\mathrm{y}$ al que Lewy llama "necesitación"?

Definición: $p$ necesita $q$ sii $(r) \quad(\sim \mathrm{M}$ ( $r$ es una razón para $p$ y $r$ es una razón para $q$ )).

(En lo que sigue, a veces se referirá al conjunto de enunciados verdaderos de necesitación como el conjunto de necesitación).

Esta definición es equivalente a $p$ necesita $q$ sii $(r)$ ( $\Gamma(r$ es una razón para $p)^{7} \rightarrow{ }^{\Gamma}(r \text { es una razón para } q)^{\urcorner}$."

El problema que plantea esta definición es que es transitiva. Por lo tanto Lewy no ha logrado resolver su problema, porque aunque (11) se leyera " $D$ Nec, $F$ ", no habría forma de abolir la verdad de $D$ implica a $E$. Si la cLP suministra algo es en todo caso las bases adicionales para aceptar la paradoja de que cualquier proposición implica cualquier proposición necesaria.

Tampoco puede Lewy mantener consistentemente la distinción entre necesitación e implicación estricta. En el sistema de necesitación, Lewy no desea que la conjunción $p \& \sim p$ necesite $p$, pero puesto que se acepta que $\left.\Gamma_{p} \& \sim p\right\urcorner-3 p$, entonces para Lewy la necesitación no es lo mismo que la implicación estricta. Si hemos de ver por qué esto es así tenemos que saber como entiende Lewy la oración "... es una razón para". $r$ es una razón para $p$ si cualquiera de las siguientes oraciones es verdadera:

(1) puesto que $r$ es verdadera, $p$ debe ser verdadera.

(2) puesto que $r$ es verdadera, $p$ es verdadera.

(3) si $r$ es verdadera, $p$ debe ser verdadera.

(4) si $r$ es verdadera, $p$ es verdadera.

(5) si $r$ fuera verdadera, $p$ sería necesariamente verdadera.

(6) si $r$ fuera verdadera, $p$ sería verdadera.

Es importante que, para que $r$ sea una razón para $p$, no es nece-

* Nota del editor. Por problemas de imprenta, y con la autorización del autor, se utiliza ' $\rightarrow$ ' con el significado 'implica estrictamente'. 
sario que $r$ implique a $p$, ni que $r$ sea una razón conclusiva para $p$, ni que $r$ sea verdadera.

¿Cómo es posible que $\left.\Gamma_{p} \& \sim p\right\rceil$ no necesite $p$ ? ¿Qué razón hay para el antecedente que no lo sea para el consecuente? Claramente la coherencia del concepto de necesitación depende de la intelegibilidad de su concepción de 'ser una razón para'. Sin embargo Lewy no ha establecido las condiciones necesarias de 'ser una razón para'. Pero, no podemos afirmar que $\Gamma_{p} \mathrm{Nec} . q^{7}$ hasta que sepamos que no existe la posibilidad de que algo sea una razón para $p$ y no lo sea para $q$. Ahora, lo que realmente cuenta aqui, no es la dificultad de este método de descubrimiento de la necesitación, sino su imposibilidad. Existen dos razones para esto: la vaguedad de 'ser una razón para' y la posibilidad conexa de que para cualquier supuesto enunciado de necesitación exista una razón que lo sea para el antecedente pero no necesariamente para el consecuente - la que es justamente la posibilidad de que todos los enunciados de necesitación sean falsos.

La vaguedad de 'ser una razón para'. En forma intuitiva se podría pensar que $\left.{ }^{r_{p}} \& \sim p\right\urcorner$ no necesita $q$. Yo puedo pensar sólo en dos razones plausibles para pensar que no haya una que sea una razón tanto para $r_{p} \& \sim p_{p}$ como para cualquier $q$ (incluyendo los casos: $q=$ p $y \quad q=\sim p)$. Considérese una concepción de 'ser una razón para' por la cual proposiciones falsas puedan ser razones, pero por lo cual proposiciones lógicamente falsas no lo puedan ser. Pero si una contradicción no puede ser una razón para ninguna proposición, entonces, a menos que proposiciones no contradictorias pudieran ser razones para contradicciones, todos los enunciados de necesitación euyos antecedentes sean contradictorios resultarian verdaderos.

En forma similar, si es posible para cualquier $r$ ser una razón para $\left.r_{p} \& \sim p\right\urcorner$, entonces es imposible para cualquier $r$ el ser una razón para $\Gamma_{p} \& \sim p^{7}$ y no una razón para alguna $q$, lo cual es sim. plemente decir que todos los enunciados de necesitación con antecedentes imposibles son verdaderos.

Gracias a las extrañas propiedades de 'ser una razón para', Lewy no puede estar en lo correcto al afirmar que $D$ Nec. $F$; aqui hay una razón para que el antecedente sea verdadero que no lo es para que el consecuente lo sea. "Si $\sim F$ y $(\sim F$ implica a $D)$ fueran verdaderas entonces $D$ sería verdadera" expresa una razón para $D$ que no es una razón para $F$.

Implicación iónica. El segundo uso que hace Lewy de 'implica', en el cual $D$ no implica a $F$ y que es transitivo, lo explica como siendo 
aquella relación que se da entre $p$ y $q$ cuando es verdad el decir que $p$ sola implica a $q$. Llamaré a esto 'implicación iónica' (1.E.)

\title{
Definición:
}

\author{
p I.E. $q$ sii (a) $p$ Nec. $q$
}

(b) es posible mostrar que $p \rightarrow q$ sin ha-

ber mostrado o asumido previamente la verdad de una proposición $r$, tal que $r$ es diferente de cualquier implicación russelliana formal, $s$, donde $p-0$ una conjunción de $p$ - está en el rango del antecedente de $s$, y $q \multimap$ una conjunción o disyunción de $q-$ está en el rango del consecuente de $s$.

Lo misterioso de la condición (b) queda un tanto aclarado en el intento de distinguir

(i) $\left\ulcorner(\text { Evelyn es un hermano })^{\top}\right.$ 1.E. $\ulcorner\text { (Evelyn es varón })^{\urcorner}$ de

(ii) $D$ I.E. $F$

(i) cumple las condiciones (a) y (b), mientras que (ii) piensa Lewy que no, ya cree que es imposible mostrar que $D \rightarrow F$ sin violar la condición (b). Lewy piensa que se debe demostrar que $E$ para demostrar que $D \rightarrow F$, donde $E$ no es una implicación formal en el sentido deseado. Sin embargo, aún si concedemos que $E$ no es la regla de inferencia adecuada, no parece que no haya otro principio que llene las especificaciones de Lewy. Se puede demostrar $\ulcorner D \rightarrow F\urcorner$ apelando al principio que afirme que no hay equivalencias materiales con antecedentes idénticos y con consecuentes que se impliquen el uno al otro mutuamente.

En suma, en el propio análisis de Lewy de la implicación iónica no se puede negar que $D$ I.E. $F$. No sólo $D$ Nec. $F$, sino que es posible probar que $D \rightarrow F$ sin el uso de una implicación russelliana no formal. Esto es desastroso para Lewy, ya que parece querer decir que en ninguno de los dos sentidos de 'implica' se elimina la paradoja.

$\mathrm{Si}$ consideramos, por ejemplo, la prueba S.2 de la segunda paradoja se puede verificar fácilmente que cada paso en el argumento está unido pro la 1.E. de Lewy, que es transitiva. Así, $p$ I.E. ( $q$ v $\sim q)$ y puesto que CLP es una ejemplificación de esto, no es una paradoja. Aun si decimos que los pasos de la prueba están relacionados por necesitación, puesto que se ha mostrado que la relación es transitiva, el resultado con respecto a la paradoja es el mismo.

Así, en ambas aplicaciones de los conceptos de Lewy de implicación, no sólo no se da la solución deseada a su propio problema, sino que se le da un apoyo adicional -como sucede con las paradojas S-2. 